\title{
Antimicrobial peptide LL-37 promotes YB-1 expression, and the viability, migration and invasion of malignant melanoma cells
}

\author{
JINJING JIA ${ }^{1}$, YAN ZHENG ${ }^{1}$, WEI WANG ${ }^{1}$, YONGPING SHAO ${ }^{2,3}$, \\ ZHENGXIAO LI ${ }^{1}$, QIONG WANG ${ }^{1}$, YUAN WANG ${ }^{1}$ and HULING YAN ${ }^{1}$ \\ ${ }^{1}$ Department of Dermatology, School of Medicine, The Second Affiliated Hospital of Xi'an Jiaotong University, Xi'an, \\ Shaanxi 710004; ${ }^{2}$ Key Laboratory of Biomedical Information Engineering of the Ministry of Education, \\ School of Life Science and Technology; ${ }^{3}$ Frontier Institute of Science and Technology, \\ Xi'an Jiaotong University, Xi'an, Shaanxi 710049, P.R. China
}

Received October 12, 2015; Accepted November 4, 2016

DOI: $10.3892 / \mathrm{mmr} .2016 .5978$

\begin{abstract}
The cathelicidin antimicrobial peptide, LL-37, is a multifunctional peptide with a broad spectrum of antimicrobial activities, such as chemotaxis and neutralizing endotoxins. Previous studies have demonstrated that it LL-37 serves a functional role in the development of numerous types of cancer including ovarian, breast, prostate and lung cancer. However, its role in the development of malignant melanoma (MM) remains unclear. To determine the role of LL-37 and the potential interaction with Y-box binding protein 1 (YB-1) in MM, RNA interference, western blot, reverse transcription-quantitative polymerase chain reaction, MTT and Transwell assays were performed. The current study demonstrated that LL-37 induced YB-1 expression, and increased tumor cell proliferation, migration and invasion of A375 and A875 MM cell lines. In addition, inhibition of nuclear factor $-\kappa \mathrm{B}(\mathrm{NF}-\kappa \mathrm{B})$ attenuated LL-37-induced YB-1 expression. These results demonstrate that, through the upregulation of YB-1 expression and the activation of the NF- $\mathrm{BB}$ signaling pathway, LL-37 may promote the malignant progression of MM cells in vitro.
\end{abstract}

\section{Introduction}

Malignant melanoma (MM) originates from melanocytes and is a highly malignant skin tumor, which accounts for $1-2 \%$ of all skin cancer cases. MM has a high malignant potential, with a high risk of ulceration and metastasis. The global incidence rates of MM have increased rapidly over the past few decades, with an annual incidence rate of 3-8\% (1-3).

Correspondence to: Dr Yan Zheng, Department of Dermatology, School of Medicine, The Second Affiliated Hospital of Xi'an Jiaotong University, 157 Xiwu Road, Xi'an, Shaanxi 710004, P.R. China

E-mail: zenyan66@126.com

Key words: LL-37, malignant melanoma, Y-box binding protein 1, nuclear factor- $\mathrm{\kappa} \mathrm{B}$
The Y-box binding protein-1 (YB-1), which contains a 'cold shock' region, is a multifunctional protein that is located in the nucleus and the cytoplasm (4). YB-1 regulates the expression of target genes indirectly or by binding to target gene sequences directly, and the altering the splicing of target genes (5-8). YB-1 expression is upregulated in a number of human tumors, including ovarian cancer, breast cancer, glioblastoma, esophageal cancer, gastric cancer, colon cancer and lung cancer (9-11), and is therefore considered to be a prognostic marker. YB-1 overexpression is an indicator of increased tumor cell proliferation, migration and invasion (9-11). Additional studies have indicated that the expression levels of YB-1, the epidermal growth factor receptor (EGFR) and the human EGFR-2 (HER-2) are collectively increased in breast cancer tissues. In addition, HER-2 may regulate the nuclear translocation of YB-1 directly or indirectly (11). In contrast to its putative oncogenic role, inhibition of YB-1 expression has been demonstrated to increase the sensitivity of melanoma cells to chemotherapy; an effect that is closely associated with the phosphatidylinositol-4,5-bisphosphate 3-kinase/AKT serine/threonine kinase 1 signaling pathway $(11,12)$. This demonstrates that the expression of YB-1 may serve a role in regulating tumor development and/or progression.

Advances in tumor biology have led to an increased focus on the potential antitumor activities of antimicrobial peptides. The human cathelicidin antimicrobial protein-18, also known as LL-37, is a key antimicrobial molecule that has been demonstrated to exhibit antitumor activities (13). It is the only member of the cathelin family in humans, and is composed of 37 amino acid residues in the C-terminal domain. LL-37 has been demonstrated to serve an important functional role in regulating innate immunity via neutrophils (13-15). In addition to its antibacterial and immune activities, LL-37 is reportedly involved in angiogenesis and cell proliferation $(14,16)$. Studies have demonstrated that LL-37 expression is upregulated in ovarian, breast, prostate and lung cancer, which may promote tumor cell proliferation, migration and invasion (17-22). The oncogenic mechanisms by which LL-37 functions may be associated with the formyl peptide receptor (FPR)-like 1, EGFR and insulin-like growth factor 1 receptor; however, the specific mechanisms remain unclear (15,23-25). In addition, 
the role of LL-37 in regulating YB-1 expression has not been elucidated.

In the present study, the effects of LL-37 on YB-1 expression on the proliferation, migration and invasion of $\mathrm{MM}$ cells were investigated. The results demonstrated that LL-37 may promote the progression of MM cells by upregulating YB-1 expression via the nuclear factor $-\kappa \mathrm{B}(\mathrm{NF}-\kappa \mathrm{B})$ signaling pathway.

\section{Materials and methods}

Cell culture. MM cell lines (A375 and A875; American Type Culture Collection, Manassas, VA, USA) were cultured in Dulbecco's modified Eagle's medium (Gibco; Thermo Fisher Scientific, Inc., Karlsruhe, Germany) containing 10\% fetal bovine serum (FBS; Gibco; Thermo Fisher Scientific, Inc.), $100 \mathrm{U} / \mathrm{ml}$ penicillin and $100 \mu \mathrm{g} / \mathrm{ml}$ streptomycin (Sigma-Aldrich; Merck Millipore, Darmstadt, Germany). Cells were maintained in a humidified chamber at $37^{\circ} \mathrm{C}$ and $5 \% \mathrm{CO}_{2}$.

Knockdown of YB-1 by small interfering RNA (siRNA). The YB-1 siRNA and negative control (NC) siRNA oligonucleotide sequences (Shanghai GenePharma Co., Ltd., Shanghai, China) employed in the present study were as follows: YB-1 siRNA 1, sense 5'-GCAGACCGUAACCAUUAUATT-3', antisense 5'-UAUAAUGGUUACGGUCUGCTT-3'; YB-1 siRNA 2, sense 5'-CGGCAAUGAAGAAGAUAAATT-3', antisense 5'-UUUAUCUUCUUCAUUGCCGTT-3'; YB-1 siRNA 3, 5'-CUGCCAUAAAGAAGAAUAATT-3', antisense 5'-UUAUUCUUCUUUAUGGCAGTT-3'; and NC siRNA, sense 5'-UUCUUCGAACGUGUCACGUTT-3' and antisense 5'-ACGUGACACGUUCGGAGAATT-3'. According to a GenBank (https://www.ncbi.nlm.nih.gov/genbank/) sequence database search, the NC siRNA used in the present study was not demonstrated to target any known mammalian gene. Cells were seeded at a density of $1 \times 10^{5}$ cells/well in 6 -well plates. When $70-80 \%$ confluence was reached $(\sim 24 \mathrm{~h}$ after seeding), the cells were transfected with siRNAs using the Lipofectamine 2000 transfection reagent (Invitrogen; Thermo Fisher Scientific, Inc.) according to the manufacturer's instructions. Transfected cells were incubated for a further $48 \mathrm{~h}$, before the inhibition rate of YB-1 expression was determined by western blot analysis.

Western blot analysis. At $4^{\circ} \mathrm{C}, \sim 2 \times 10^{6}$ cells were lysed with 100-400 $\mu \mathrm{l}$ of a mixture comprising PBS, $5 \mathrm{mM}$ EDTA, $0.5 \%$ Triton X-100, $20 \mathrm{mM} \mathrm{NaF}, 1 \mathrm{mM}$ orthovanadate, $1 \mathrm{mM}$ pyrophosphate and protease inhibitors $(0.1 \mathrm{mM}$ PMSF, $10 \mu \mathrm{M}$ pepstatin A, $10 \mu \mathrm{M}$ leupeptin and $25 \mu \mathrm{g} / \mathrm{ml}$ aprotinin) for $30 \mathrm{~min}$, and then the cell lysates were centrifuged $(13,523 \mathrm{x} \mathrm{g}$, $\left.4^{\circ} \mathrm{C}, 15 \mathrm{~min}\right)$. Protein extracts $(20 \mu \mathrm{g})$ were separated using $10 \%$ SDS-PAGE and then transferred to a polyvinylidene difluoride membrane. The membrane was blocked using 5\% non-fat milk in a $0.1 \%$ Tween-20-phosphate buffer solution and incubated at room temperature for $1 \mathrm{~h}$. Membranes were subsequently incubated with the rabbit anti-human YB-1 monoclonal antibody (1:500 dilution; cat. no. ab12148; Abcam, Cambridge, UK) and $\beta$-actin antibody (cat. no. sc-47778; Santa Cruz Biotechnology, Inc., Dallas, TX, USA) at $4^{\circ} \mathrm{C}$ overnight.
The membranes were then incubated with a goat anti-rabbit horseradish peroxidase-conjugated secondary antibody (1:5,000 dilution; cat. no. sc-2004; Santa Cruz Biotechnology, Inc.) for $1 \mathrm{~h}$ at room temperature, and visualized using a chemiluminescence substrate (EMD Millipore, Billerica, MA, USA). Chemiluminescence was detected using an X-ray film.

Analysis of the viability and migration of cells transfected with YB-1 siRNA. Transfected cells were seeded at a density of $3 \times 10^{3}$ cells/well in 96 -well plates. Following $12 \mathrm{~h}$, the medium was replaced with serum-free medium and the cells were cultured for a further $24 \mathrm{~h}$. A total of $10 \mu \mathrm{l}(5 \mathrm{mg} / \mathrm{ml})$ MTT reagent (Sigma-Aldrich; Merck Millipore) was added to each well, and cells were incubated under normal conditions for a further $4 \mathrm{~h}$. Following the addition of $150 \mu \mathrm{l}$ dimethyl sulfoxide (Sigma-Aldrich; Merck Millipore), the absorbance was read at $490 \mathrm{~nm}$ using a microplate reader (Bio-Rad Laboratories, Inc., Hercules, CA, USA). A cell invasion assay was performed using Transwell chambers (Costar; Corning Life Sciences, Inc., Corning, NY, USA) pre-coated with Matrigel matrix (BD Biosciences, Heidelberg, Germany). Briefly, transfected cells were incubated without serum for $12 \mathrm{~h}$ before they were resuspended in serum-free medium at a concentration of $2.5 \times 10^{5}$ cells $/ \mathrm{ml}$. A total of $200 \mu \mathrm{l}$ cell suspension was added to the upper Transwell chamber, while $500 \mu \mathrm{l}$ of culture medium containing $10 \%$ FBS was added to the lower chamber. Following incubation for $24 \mathrm{~h}$, residual cells in the upper chamber were removed, and cells that had invaded the lower chamber were stained with a staining solution $(0.1 \%$ crystal violet ethanol). A total of three randomly selected representative fields of view were visualized under a microscope (magnification, $\mathrm{x} 200$ ) and the average number of invaded cells was calculated.

Cell viability assay following LL-37 stimulation. Cells $\left(3 \times 10^{3}\right.$ cells/well) were seeded in 96-well plates and cultured in the absence of serum for $24 \mathrm{~h}$. LL-37 (Sigma-Aldrich; Merck Millipore) was then added at the $0,0.05,0.5,5$ and $20 \mu \mathrm{g} / \mathrm{ml}$ at 24, 48 and $72 \mathrm{~h}$ after the cells were seeded. An MTT assay was used to examine cell viability using the aforementioned procedure.

Cell migration and invasion assays following LL-37 stimulation. Transwell chambers were used to examine cell migration and invasion following LL-37 stimulation according to the aforementioned Transwell assay procedures. In the upper chamber, a $0,0.05,0.5$ or $5 \mu \mathrm{g} / \mathrm{ml}$ LL-37 was added. Matrigel matrix-coated chambers were used to determine cell invasion, while cell migration was determined using uncoated chambers.

Total RNA extraction and reverse transcription-quantitative polymerase chain reaction $(R T-q P C R)$. TRIzol reagent (Sigma-Aldrich; Merck Millipore) was used to extract total RNA from cells following treatment with LL-37. Total RNA was then reverse transcribed into cDNA using an RT reaction kit (Promega Corporation, Madison, WI, USA) according to the manufacturer's instructions. RT-qPCR analysis of YB-1 and $\beta$-actin mRNA expression levels was conducted using SYBR Premix Ex Taq II (Takara Biotechnology Co., Ltd, Dalian, China) and an Mx3000P qPCR system (Applied Biosystems; 
Thermo Fisher Scientific, Inc.). Reaction mixtures contained $5 \mu \mathrm{l}$ cDNA (diluted 1:5), $1 \mu \mathrm{l}$ forward primer, $1 \mu \mathrm{l}$ reverse primer, $10 \mu 1$ qPCR Master Mix 10 and $3 \mu 1$ nuclease-free water. Thermal cycling parameters consisted of 50 cycles of $95^{\circ} \mathrm{C}$ for $10 \mathrm{sec}$ and $60^{\circ} \mathrm{C}$ for $30 \mathrm{sec}$. The primer sequences were as follows: Human $Y B-1$ forward, 5'-CAGAATAGTGAG AGTGGGG-3', and reverse, 5'- ATGTAGTAAGGTGGGAAC C-3'; Human $\beta$-actin forward, 5'-TTCCATATCGTCCCAGTT GGT-3', and reverse, 5'-CCAGGGCGTTATGGTAGGCA-3'. mRNA levels were calculated using the $2^{-\Delta \Delta \mathrm{Cq}}$ method (26).

Immunofluorescence staining. Following the transfer of a monolayer of cells $\left(\sim 3 \times 10^{5}\right.$ cells $)$ to a cell climbing film (Medical Equipment Factory, Xi'an Jiaotong University, Xi'an, China), LL-37 was added at $0,0.05,0.5$ or $5 \mu \mathrm{g} / \mathrm{ml}$ and incubated for $48 \mathrm{~h}$. Cells were subsequently fixed with $4 \%$ paraformaldehyde at room temperature for $10 \mathrm{~min}$, and then treated with $5 \%$ Triton X-100 for 15 min followed by $1 \%$ goat serum for $30 \mathrm{~min}$. Cells were incubated with the rabbit anti-human YB-1 monoclonal antibody (1:50 dilution) overnight at $4^{\circ} \mathrm{C}$. Cells were subsequently incubated with a fluorescein isothiocyanate-labeled goat anti-rabbit antibody [from KIT-9710; UltraSensitive ${ }^{\mathrm{TM}}$ SP (Mouse/Rabbit) IHC Kit; Fuzhou Maixin Biotechnology Co., Ltd., Fuzhou, China] at $37^{\circ} \mathrm{C}$ for $1 \mathrm{~h}$, and then stained with DAPI (Sigma-Aldrich; Merck Millipore) for $1 \mathrm{~min}$. Staining intensities were visualized using an inverted fluorescence microscope (LSM 700; Zeiss AG, Oberkochen, Germany).

Signal transduction pathway analysis. Cells were seeded at $1 \times 10^{5}$ cells/well in 6-well plates. They were initially treated with $10 \mu \mathrm{M}$ mitogen-activated protein kinase kinase (MEK) inhibitor (PD98059), $10 \mu \mathrm{M} \mathrm{p38/mitogen-activated} \mathrm{protein}$ kinase (p38/MAPK) inhibitor (SB203580) or $1 \mu \mathrm{M} \mathrm{NF}-\kappa \mathrm{B}$ inhibitor (PDTC; all from Abcam), for 30 min. Cells were subsequently treated with $0.5 \mu \mathrm{M}$ LL-37 for a further $24 \mathrm{~h}$. The protein expression levels of YB-1 and $\beta$-actin were then determined by western blot analysis using the aforementioned procedures.

Statistical analysis. Data are presented as the mean \pm standard deviation. Statistical significance between two groups was determined using the Student's $t$-test or one-way analysis of variance with least significant difference post-hoc test. $\mathrm{P}<0.05$ was considered to indicate a statistically significant difference.

\section{Results}

YB-1 siRNA transfection inhibits YB-1 protein expression and reduces the viability and invasion of $M M$ cells. Total protein was extracted from A375 and A875 MM cells at $48 \mathrm{~h}$ following transfection with YB-1 siRNA, and YB-1 protein expression levels were determined by western blotting. Compared with the control group (transfected with non-targeting siRNA), the protein expression levels of YB-1 in YB-1 siRNA-transfected cells were significantly reduced (Fig. 1A). Initially, three siRNAs were tested and the most effective siRNA (siRNA1 in A375 cells and siRNA2 in A875 cells) were used in the following studies. In addition, the viability of YB-1 siRNA-transfected A375 and A875 cells was significantly decreased at $24 \mathrm{~h}$ following transfection when compared with the control group ( $\mathrm{P}=0.016$ in $\mathrm{A} 375$ cells; $\mathrm{P}=0.018$ in A875 cells; Fig. 1B), indicating that the YB-1 may regulate MM tumor cell viability. Results from the Transwell invasion assay demonstrated that the number of YB-1 siRNA-transfected cells that traversed the membrane following $24 \mathrm{~h}$ was significantly lower when compared with that in the control transfection group $(\mathrm{P}=0.026$ in $\mathrm{A} 375$ cells; $\mathrm{P}=0.021$ in A875 cells; Fig. 1C). This suggests that YB-1 may control tumor cell invasion. Therefore, YB-1 depletion may reduce the viability and invasiveness of A375 and A875 cells in vitro.

LL-37 treatment increases the viability of MM cells. In order to investigate the effect of LL-37 treatment on the viability of MM cells, A375 and A875 cells were exposed to increasing concentrations of LL-37 for 24, 48 and $72 \mathrm{~h}$. Compared with the untreated group, exposure to $0.05,0.5$ and $5 \mu \mathrm{g} / \mathrm{ml} \mathrm{LL}-37$ was associated with an increase in cell viability at all time points. A statistically significant increase was observed following exposure of the two cell lines to $0.5 \mu \mathrm{g} / \mathrm{ml}$ at all time points, with the exception of A375 cells treated for $72 \mathrm{~h}$ $(\mathrm{P}=0.003$ in $\mathrm{A} 375$ cells; $\mathrm{P}=0.001$ in $\mathrm{A} 875$ cells; Fig. 1D).

LL-37 promotes the migration and invasion of MM cells. Compared with the untreated control group, exposure of A375 and A875 cells to $0.05,0.5$ and $5 \mu \mathrm{g} / \mathrm{ml} \mathrm{LL-37} \mathrm{was}$ associated with an increase in cell migration after $12 \mathrm{~h}$ ( $\mathrm{P}=0.018$, Fig. 2A; and $\mathrm{P}=0.001$, Fig. $2 \mathrm{~B}$ ) and invasion after $24 \mathrm{~h}(\mathrm{P}=0.011$, Fig. $2 \mathrm{C}$; and $\mathrm{P}=0.015$, Fig. 2D). A statistically significant increase in A375 and A875 cell migration and invasion was observed following exposure to $0.5 \mu \mathrm{g} / \mathrm{ml}$ LL-37 at both time points.

LL-37 promotes YB-1 expression in MM cells. Compared with the untreated control, exposure of A375 and A875 cells to $0.5 \mu \mathrm{g} / \mathrm{ml} \mathrm{LL}-37$ for $24 \mathrm{~h}$, was associated with a significant increase in YB-1 mRNA expression levels $[\mathrm{P}=0.048$ (time) and $\mathrm{P}=0.031$ (dose) in $\mathrm{A} 375$ cells; $\mathrm{P}=0.012$ (time) and $\mathrm{P}=0.023$ (dose) in A875 cells; Fig. 3A]. Western blot analysis of YB-1 protein expression demonstrated that exposure to LL-37 for $48 \mathrm{~h}$ led to a marked increase in YB-1 protein expression levels within A375 and A875 cells, with the most notable increase observed at a concentration of $0.5 \mu \mathrm{g} / \mathrm{ml}$ (Fig. 3B and C). These results were confirmed by immunofluorescence staining of YB-1 in cells following exposure to increasing concentrations of LL-37, which demonstrated increased fluorescence intensities (Fig. 4A). The most notable increase in YB-1 expression was observed following exposure of A375 and A875 cells to $0.5 \mu \mathrm{g} / \mathrm{ml} \mathrm{LL-37} \mathrm{(Fig.} \mathrm{4A).}$ These results suggest that LL-37 promoted the expression of YB-1 in A375 and A875 cells.

Inhibition of the $N F-\kappa B$ signalling pathway prevents LL-37-mediated induction of YB-1 expression. Based on earlier results demonstrating that YB-1 expression induced by LL-37 was mediated by the NF- $\mathrm{KB}$ signalling pathway in ovarian cancer cells (27), the role of the NF- $\mathrm{KB}$ signalling pathway in mediating this effect in MM cells was investigated. 
$\mathbf{A}$
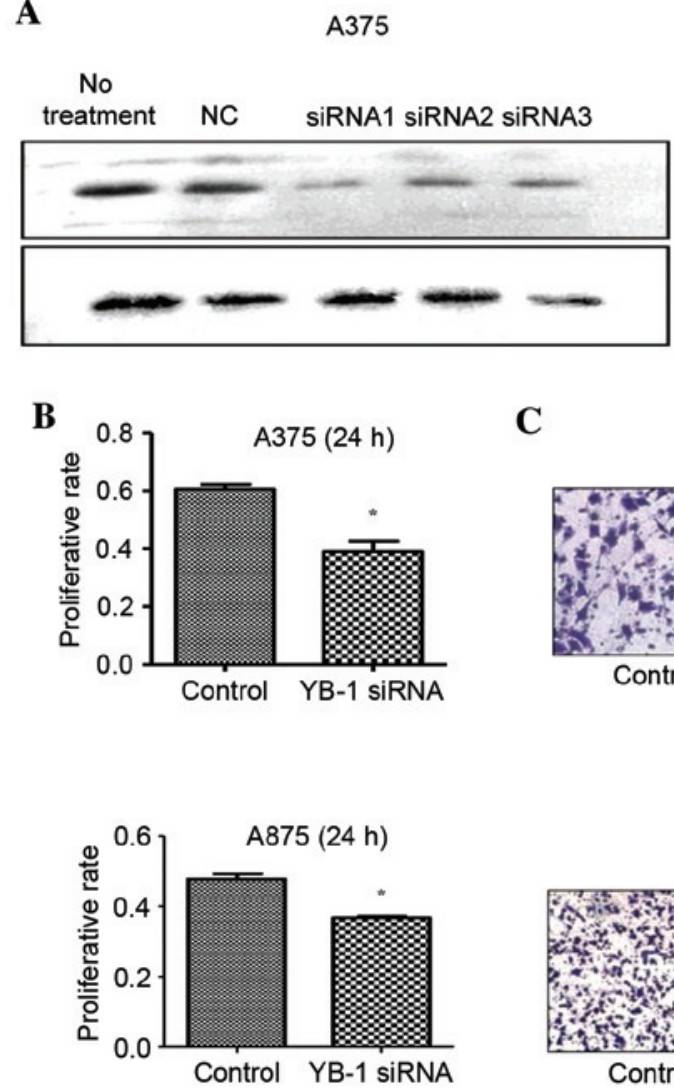

D

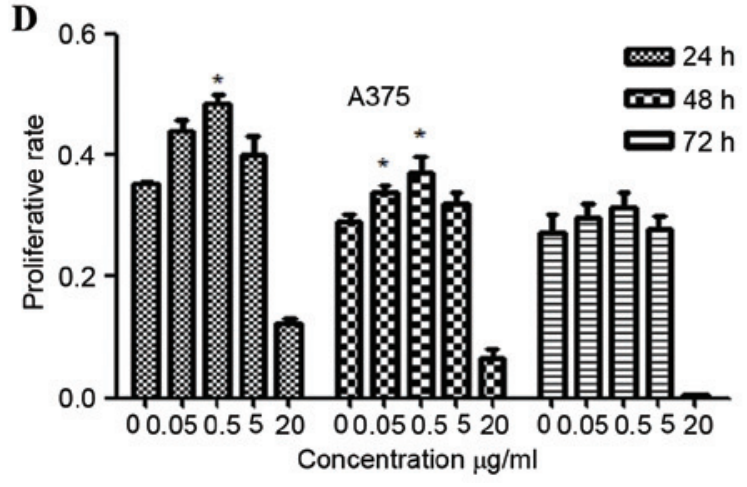

C
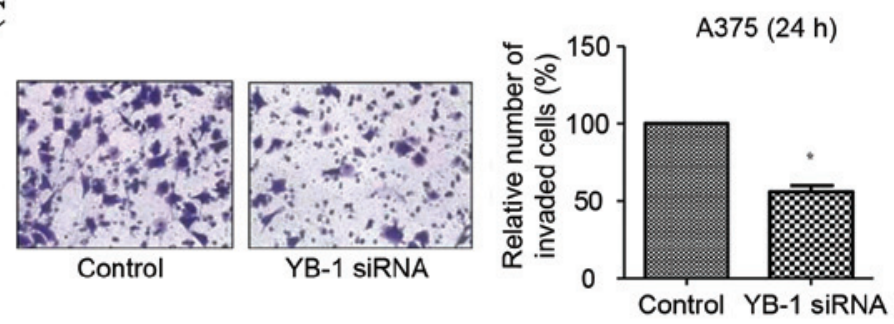

$\mathrm{A} 875$

YB-1

$(50 \mathrm{kDa})$

$\beta$-actin

$(43 \mathrm{kDa})$

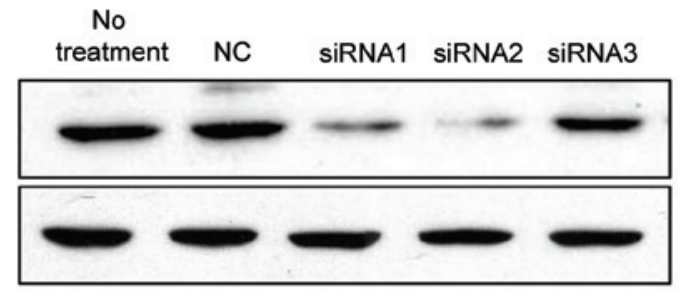

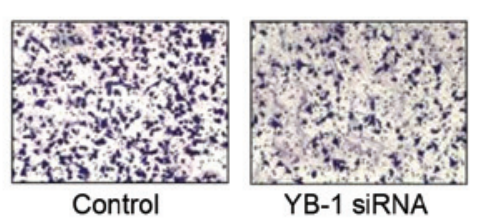

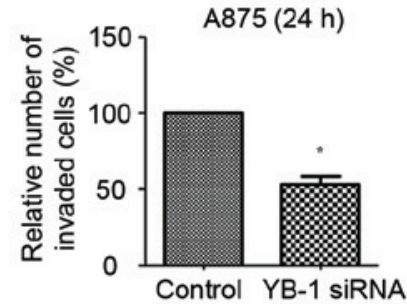

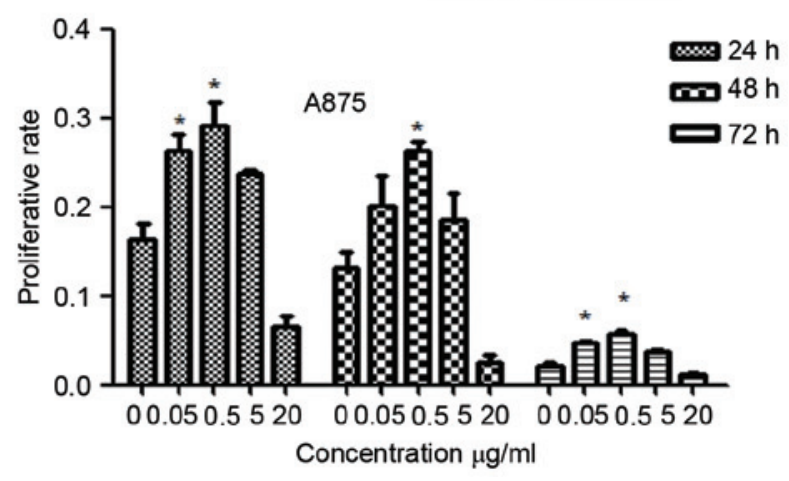

Figure 1. Effect of YB-1 knockdown on MM cell viability and invasion, and the effect of LL-37 exposure on MM cell viability. (A) Western blot analysis showed that siRNA1 in A375 cells and siRNA2 in A875 cells successfully reduced YB-1 protein expression. (B) Cell viability was reduced in A375 and A875 cells following YB-1 siRNA transfection, as demonstrated by MTT assay analysis. (C) The Transwell invasion assay demonstrated that the number of invaded cells was reduced at $24 \mathrm{~h}$ following transfection with YB-1 siRNA (magnification, x200). (D) The viability of A375 and A875 cells following exposure to $0,0.05,0.5,5$ and $20 \mu \mathrm{g} / \mathrm{ml} \mathrm{LL}-37$ for 24,48 and $72 \mathrm{~h}$ as determined by MTT assay. Data are presented as mean \pm standard deviation of three independent experiments, with five samples in each treatment group. ${ }^{*} \mathrm{P}<0.05$ vs. control (non-targeting siRNA) or $0 \mu \mathrm{g} / \mathrm{ml} \mathrm{LL}-37$. YB-1, Y-box binding protein 1 ; MM, malignant melanoma.

To do this, A375 and A875 cells were treated with a MEK inhibitor (PD98059), a p38/MAPK inhibitor (SB203580), or a NF- $\kappa \mathrm{B}$ inhibitor (PDTC) prior to treatment with LL-37. The $\mathrm{p} 38 / \mathrm{MAPK}$ and $\mathrm{NF}-\kappa \mathrm{B}$ inhibitors significantly reduced LL-37-induced YB-1 protein expression levels in A375 cells, whereas the MEK and NF- $\mathrm{B}$ inhibitors significantly reduced the expression in A875 cells. Thus, the NF- $\kappa \mathrm{B}$ inhibitor PDTC significantly decreased the LL-37-induced expression of YB-1 in both cell lines $(\mathrm{P}=0.001$ in $\mathrm{A} 375$ cells; $\mathrm{P}=0.002$ in $\mathrm{A} 875$ cells; Fig. 4B). These results suggest that the $\mathrm{NF}-\kappa \mathrm{B}$ signaling pathway may serve a role in mediating the induction of $\mathrm{YB}-1$ expression by LL-37 in MM cells.

\section{Discussion}

LL-37 is a member of the antimicrobial peptide family, and its expression is correlated with the proliferation of epidermal cells $(13,14)$. Previous studies have demonstrated that LL-37 may promote the progression of numerous malignant tumors, including lung, ovarian and prostate cancer, as well as oral squamous cell carcinoma. LL-37-mediated tumor progression is suggested to be associated with the upregulation of EGFR and the HER-2 receptor tyrosine kinase (15,23-25,28). LL-37 transactivates the EGFR via matrix metallopeptidase (MMP)-mediated cleavage of membrane-anchored 


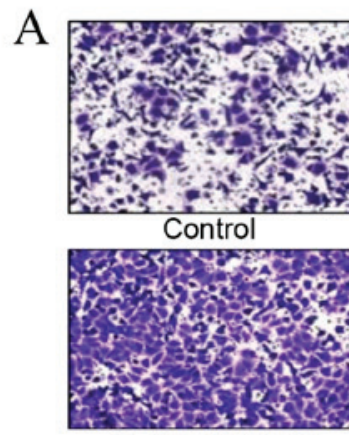

LL-37 $0.5 \mu \mathrm{g} / \mathrm{ml}$

B

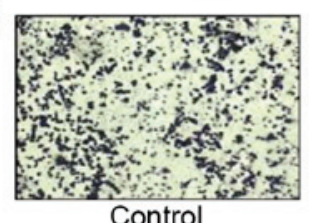

Control

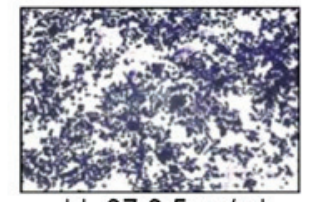

$\mathrm{LL}-370.5 \mu \mathrm{g} / \mathrm{ml}$

$\mathrm{C}$
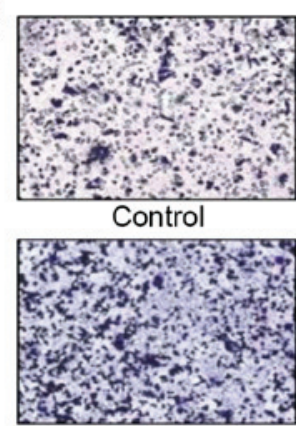

$\mathrm{LL}-370.5 \mu \mathrm{g} / \mathrm{m}$

D
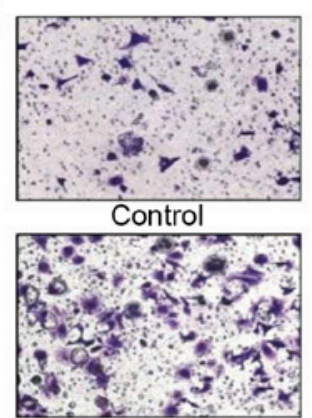

LL-37 $0.5 \mu \mathrm{g} / \mathrm{ml}$

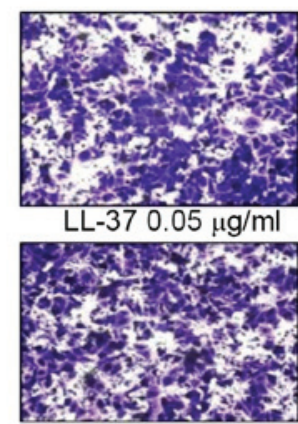

$\mathrm{LL}-375 \mu \mathrm{g} / \mathrm{ml}$

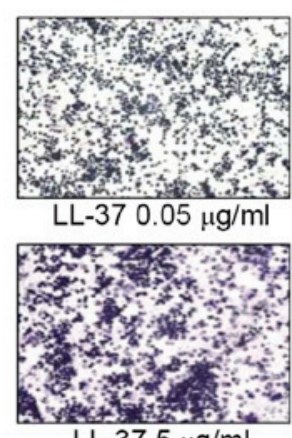

$\mathrm{LL}-375 \mu \mathrm{g} / \mathrm{ml}$

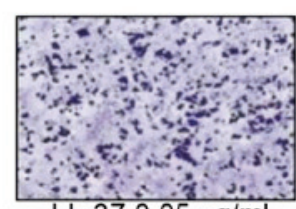

LL-37 $0.05 \mu \mathrm{g} / \mathrm{ml}$
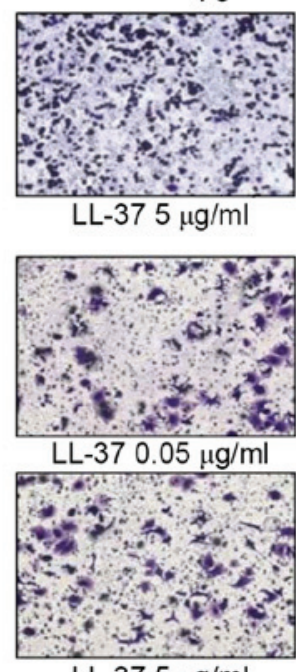

LL-37 $5 \mu \mathrm{g} / \mathrm{ml}$

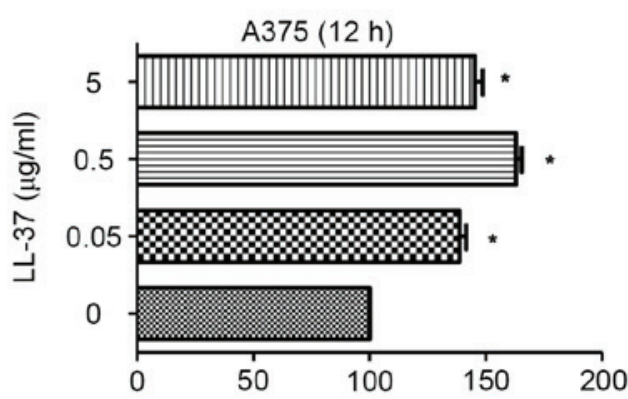

Relative number of migrated cells (\%)
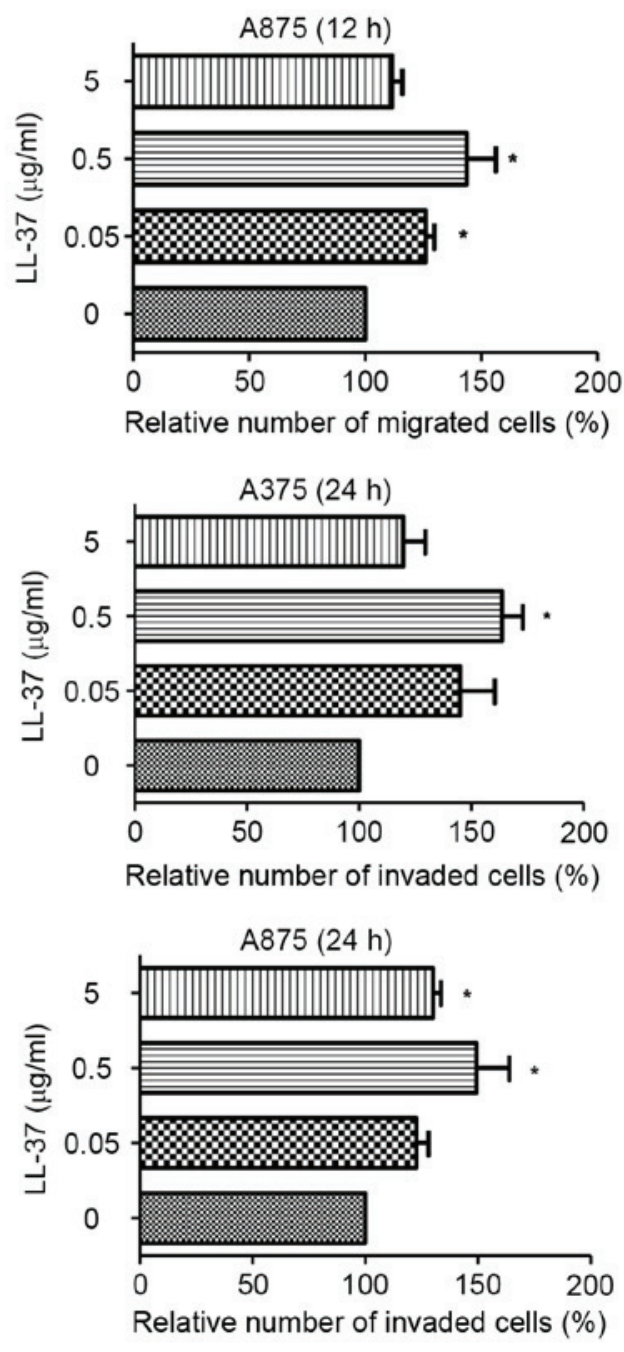

Figure 2. LL-37 increases the migration and invasion of MM cells. The relative migration of (A) A375 and (B) A875 cells, and the relative invasion of (C) A375 and (D) A875 cells following exposure to $0,0.05,0.5$ and $5 \mu \mathrm{g} / \mathrm{ml} \mathrm{LL}-37$ for 12 and $24 \mathrm{~h}$, respectively, as determined using Transwell assays (magnification, $\mathrm{x} 200)$. Data represent the mean \pm standard deviation of three randomly selected fields of view. ${ }^{*} \mathrm{P}<0.05 \mathrm{vs} .0 \mu \mathrm{g} / \mathrm{ml}$ LL-37. LL-37, cathelicidin antimicrobial peptide; MM, malignant melanoma.

EGFR-ligands (29), which may depend on G-protein-coupled receptors (15,23-25). In lung squamous cell carcinoma, LL-37 stimulates the proliferation and invasion of tumor cells via its mitogenic effect on EGFR phosphorylation, and the subsequent activation of the Ras/MAPK signaling cascade (22). EGFR signaling in lung cancer cells serves a direct role in promoting cell proliferation, anti-apoptotic signaling pathways, angiogenesis, invasion and metastasis $(15,22)$. The majority of EGFR ligands, such as transforming growth factor and heparin-binding epidermal growth factor, are soluble transmembrane precursors, which are released following proteolytic cleavage $(24,30,31)$. These precursors diffuse freely, and bind to and activate the EGFR. Thus, the oncogenic effects of LL-37 in specific tissues may be mediated by the activation of EGFR $(24,30,31)$. In breast cancer, LL-37 promotes tumor progression via activation of the HER-2-mediated signaling 

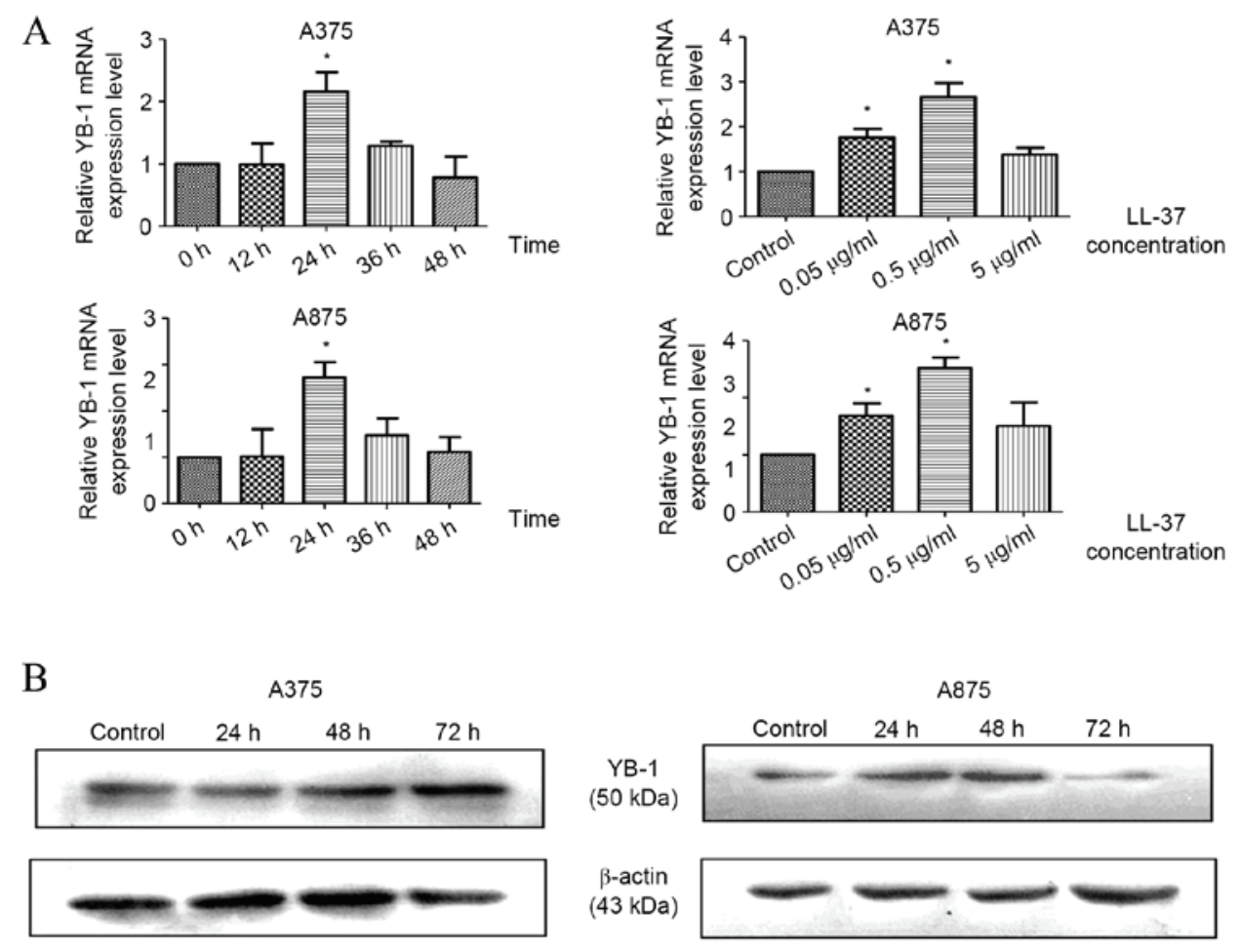

$\mathrm{C}$

A375

Control $0.05 \mu \mathrm{g} / \mathrm{ml} \quad 0.5 \mu \mathrm{g} / \mathrm{ml} \quad 5 \mu \mathrm{g} / \mathrm{ml}$

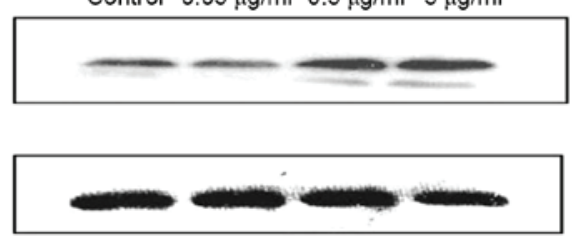

A875

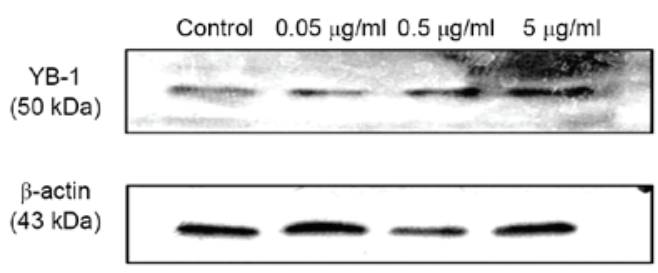

Figure 3. LL-37 promotes YB-1 expression in A375 and A875 cells. (A) Reverse transcription-quantitative polymerase chain reaction analysis of YB-1 mRNA expression in cells exposed to $0.5 \mu \mathrm{g} / \mathrm{ml} \mathrm{LL}-37$ for $0,12,24,36$ or $48 \mathrm{~h}$ or exposed to $0,0.05,0.5$ and $5 \mu \mathrm{g} / \mathrm{ml} \mathrm{LL}-37$ for $24 \mathrm{~h}$. The mRNA levels of YB-1 are shown relative to $\beta$-actin mRNA. Western blot analysis of YB-1 protein expression levels in A375 and A875 cells following exposure to (B) $0.5 \mu \mathrm{g} / \mathrm{ml} \mathrm{LL}-37$ for $0,24,48$ and $72 \mathrm{~h}$, and (C) $0,0.05,0.5$ and $5 \mu \mathrm{g} / \mathrm{ml} \mathrm{LL}-37$ for $48 \mathrm{~h}$. Data are presented as the mean \pm standard deviation of three independent experiments. ${ }^{*} \mathrm{P}<0.05$ vs. control. LL-37, cathelicidin antimicrobial peptide; YB-1, Y box binding protein 1; MM, malignant melanoma.

pathway, which may also be mediated by FPR2 (20). LL-37 triggers the activation of MAPK and the Janus kinase signal transducer in a biochemical cascade that leads to the activation of multiple transcription factors. This process may be dependent or independent of FPR2 $(23,25,32)$. LL-37 enhances the invasiveness of ovarian cancer cells by increasing the activity of tissue remodelling enzymes, such as the MMP-2 (21,24,30,31). FPR2 in ovarian cancer cells increases the expression of MMP-2, thus inhibiting or blocking LL-37 receptors and promoting tumor cell invasiveness $(21,24,30,31)$.

Previous studies have demonstrated that YB-1 regulates epithelial cell proliferation and is overexpressed in numerous tumors (33-36). In transgenic mice, an increase in FPR2 expression promotes the transcription of YB-1 $(12,37)$. Previous studies have demonstrated that Y-box family proteins may mediate the regulation of EGFR and HER-2 expression by binding to the enhancer and promoter regions of these genes, respectively $(7,9)$. An additional study demonstrated that upregulation of YB-1 is mediated by the upregulation of extracellular signal-regulated kinase 2 (ERK2) and glycogen synthase kinase-3 (GSK-3 $\beta$ ) activity. ERK2 and GSK-3 $\beta$ activity is critical for cell proliferation and apoptosis. Therefore, YB-1 may be a downstream target of ERK2 and GSK-3 $\beta(11,38)$.

To the best of our knowledge, no previous report has demonstrated the interaction between LL-37 and YB-1. However, the current study demonstrated that LL-37, which shares certain common features with YB-1, may promote the progression and malignant biological behavior of numerous malignant tumors. The results of the present study demonstrated that knockdown of YB-1 expression inhibits the viability and invasion of A375 and A875 MM cells in vitro. Following exposure to 0.05-5 $\mu \mathrm{g} / \mathrm{ml} \mathrm{LL}-37, \mathrm{~A} 375$ and A875 cells exhibited an increase in YB-1 expression. These results suggest that LL-37 may function to upregulate YB-1 expression MM cells. Previous studies have reported that LL-37 increases the malignant potential of tumor cells, which may be associated with activation of the Ras/MAPK and NF- $\kappa$ B signaling pathways $(39,40)$. Therefore, ERK, MAPK and $\mathrm{NF}-\kappa \mathrm{B}$ inhibitors were employed in the present study to investigate the role of the $\mathrm{NF}-\kappa \mathrm{B}$ signaling pathway in mediating 


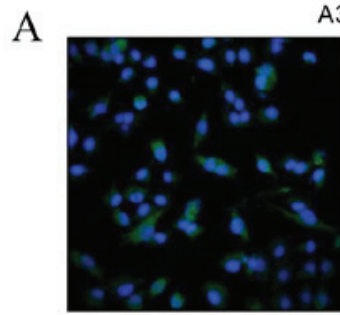

Control

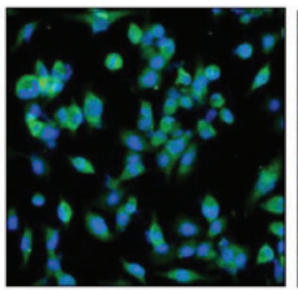

LL-37 $0.5 \mu \mathrm{g} / \mathrm{ml}$
A375

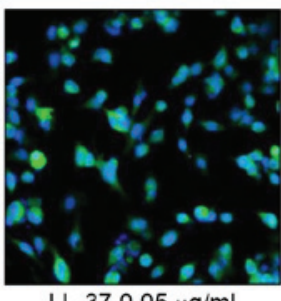

LL-37 $0.05 \mu \mathrm{g} / \mathrm{ml}$

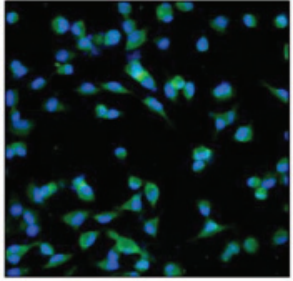

$\mathrm{LL}-375 \mu \mathrm{g} / \mathrm{ml}$

A375
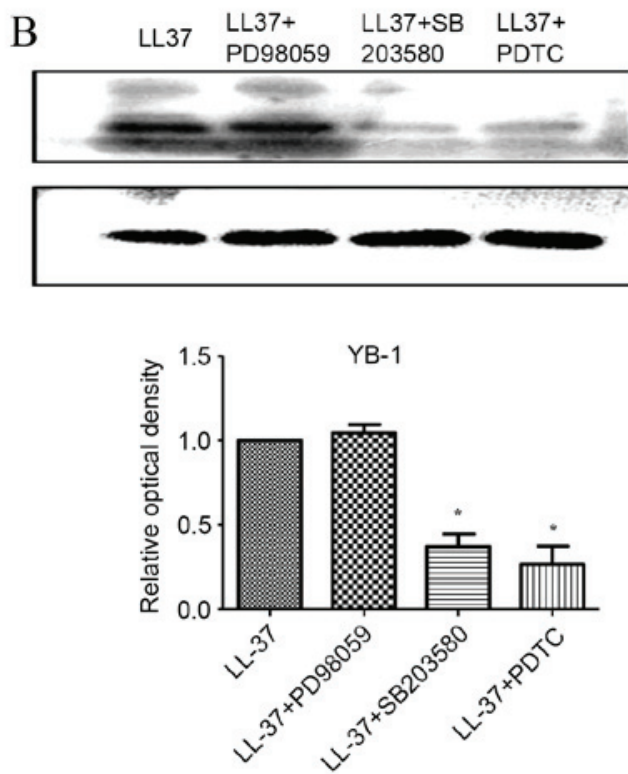

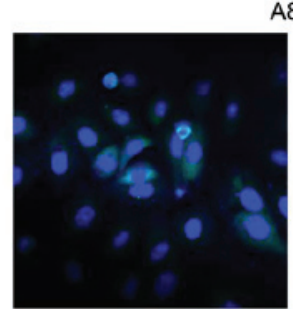

Control

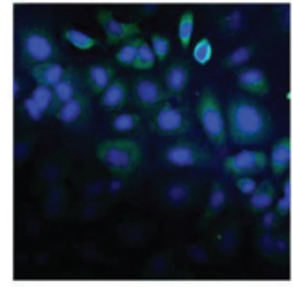

$\mathrm{LL}-370.5 \mu \mathrm{g} / \mathrm{ml}$
A875

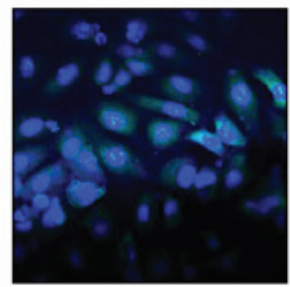

LL-37 $0.05 \mu \mathrm{g} / \mathrm{ml}$

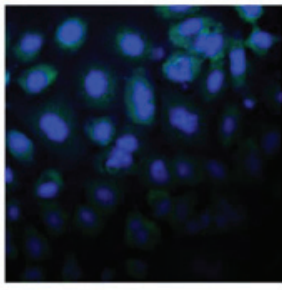

$\mathrm{LL}-375 \mu \mathrm{g} / \mathrm{ml}$

A875

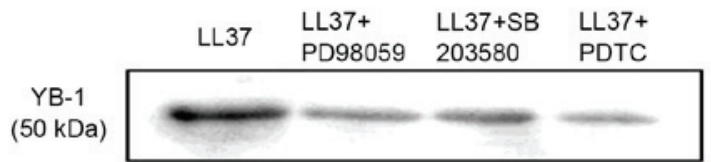

$\beta$-actin (43 kDa)

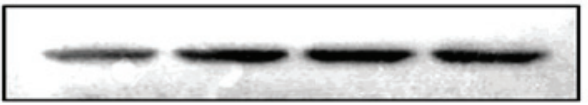

YB-1

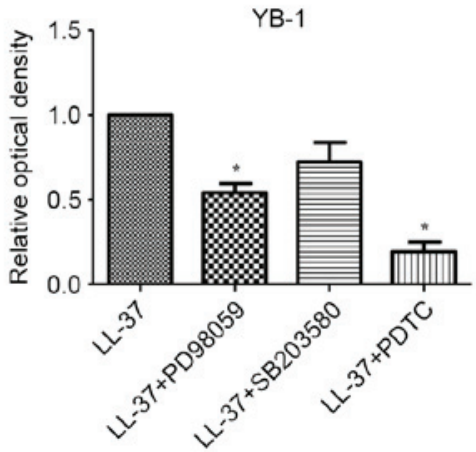

Figure 4. LL-37-induced YB-1 expression in MM cells is attenuated by inhibition of members of the NF- $\kappa$ B signaling pathway. (A) Immunofluorescence staining of YB-1 expression in A375 and A875 cells following exposure to various concentrations of LL-37 for 48 h (magnification, $\mathrm{x} 400$ ). (B) Western blot analysis of YB-1 protein expression levels following treatment of A375 and A875 cells with LL-37, LL-37 + $10 \mu \mathrm{M}$ mitogen-activated protein kinase kinase inhibitor (PD98059), LL-37 $+10 \mu \mathrm{M}$ p38/mitogen-activated protein kinase inhibitor (SB203580) or LL-37 + $1 \mu \mathrm{M}$ NF- $\kappa \mathrm{B}$ inhibitor (PDTC). The NF- $\kappa \mathrm{B}$ signaling pathway was involved in the upregulation of YB-1 stimulated by LL-37. Protein expression levels are shown relative to $\beta$-actin. Data are presented as the mean \pm standard deviation of three independent experiments. ${ }^{*} \mathrm{P}<0.05$ vs. LL-37. LL-37, cathelicidin antimicrobial peptide; YB-1, Y box binding protein 1; $\mathrm{MM}$, malignant melanoma; $\mathrm{NF}-\kappa \mathrm{B}$, nuclear factor- $\kappa \mathrm{B}$.

LL-37-induced YB-1 expression. Inhibition of NF- $\kappa$ B in A375 and A875 cell lines significantly reduced the LL-37-induced YB-1 protein expression. These results suggest that LL-37 may upregulate $\mathrm{YB}-1$ expression via the NF- $\kappa \mathrm{B}$ signaling pathway. LL-37-mediated activation of EGFR and HER-2 is accompanied by the phosphorylation of EGFR and activation of the subsequent Ras/MAPK cascade, thereby promoting the expression of MMP-2 via FPR2. In addition, EGFR, HER-2 and FPR2 may regulate YB-1 expression (22,23), and the overexpression of these factors may enhance tumor cell proliferation and invasion. This suggests that, LL-37 may promote the proliferation and invasion of A375 and A875 cells through the upregulation of YB-1 expression. NF- $\kappa \mathrm{B}$ is a transcription factor that is known to regulate the expression of multiple genes, and is involved in a wide range of cellular responses $(41,42)$. NF- $\kappa \mathrm{B}$ activation serves a significant role in promoting tumor metastasis, and inhibition of $N F-\kappa B$ can prevent the induction of apoptosis $(41,42)$.

In conclusion, the results of the present study are consistent with the reported role of YB-1 as a marker of malignancy in MM. In addition, the antimicrobial peptide LL-37 was demonstrated to upregulate YB-1 expression and promote the viability, migration and invasion of A375 and A875 cells in vitro. Furthermore, the NF- $\kappa \mathrm{B}$ signaling pathway may mediate LL-37-induced YB-1 expression. This study provides a novel insight into the association between LL-37 and YB-1 in $\mathrm{MM}$, and provides potential therapeutic targets for the treatment of MM. 


\section{Acknowledgements}

This study was supported by the National Natural Science Foundation of China (grant nos. 81071299, 81371732 and 81573055 ) and was partially supported by the Fundamental Research Funds for the Central Universities and for Changjiang Scholars and Innovative Research Team in University (grant no. PCSIRT:1171).

\section{References}

1. Meier F, Satyamoorthy K, Nesbit M, Hsu MY, Schittek B Garbe C and Herlyn M: Molecular events in melanoma development and progression. Front Biosci 3: D1005-D1010, 1998.

2. Eigentler TK, Caroli UM, Radny P and Garbe C: Palliative therapy of disseminated malignant melanoma: A systematic review of 41 randomised clinical trials. Lancet Oncol 4: 748-759, 2003.

3. Bekele S, Bekele Y, Mulatu F, Lemma T, Tilahun H, Gadisa E, Negussie S, Yamuah L, Wassie L, Abebe M, et al: Recent trends of cutaneous leishmaniasis in Alert Hospital, Addis Ababa. Ethiop Med J (Suppl 1): S37-S41, 2014.

4. Kosnopfel C, Sinnberg T and Schittek B: Y-box binding protein 1-a prognostic marker and target in tumour therapy. Eur J Cell Biol 93: 61-70, 2014.

5. Sakura H, Maekawa T, Imamoto F, Yasuda K and Ishii S: Two human genes isolated by a novel method encode DNA-binding proteins containing a common region of homology. Gene 73: 499-507, 1988

6. Eliseeva IA, Kim ER, Guryanov SG, Ovchinnikov LP and Lyabin DN: Y-box-binding protein 1 (YB-1) and its functions. Biochemistry (Mosc) 76: 1402-1433, 2011.

7. Shiota M, Izumi H, Onitsuka T, Miyamoto N, Kashiwagi E, Kidani A, Yokomizo A, Naito S and Kohno K: Twist promotes tumor cell growth through YB-1 expression. Cancer Res 68: 98-105, 2008.

8. Lasham A, Samuel W, Cao H, Patel R, Mehta R, Stern JL, Reid G, Woolley AG, Miller LD, Black MA, et al: YB-1, the E2F pathway, and regulation of tumor cell growth. J Natl Cancer Inst 104: 133-146, 2012.

9. Lasham A, Print CG, Woolley AG, Dunn SE and Braithwaite AW: YB-1: Oncoprotein, prognostic marker and therapeutic target? Biochem J 449: 11-23, 2013.

10. Takahashi M, Shimajiri S, Izumi H, Hirano G, Kashiwagi E, Yasuniwa Y, Wu Y, Han B, Akiyama M, Nishizawa S, et al: Y-box binding protein-1 is a novel molecular target for tumor vessels. Cancer Sci 101: 1367-1373, 2010.

11. Stratford AL, Habibi G, Astanehe A, Jiang H, Hu K, Park E, Shadeo A, Buys TP, Lam W, Pugh T, et al: Epidermal growth factor receptor (EGFR) is transcriptionally induced by the Y-box binding protein-1 (YB-1) and can be inhibited with Iressa in basal-like breast cancer, providing a potential target for therapy. Breast Cancer Res 9: R61, 2007.

12. Schittek B, Psenner K, Sauer B, Meier F, Iftner T and Garbe C: The increased expression of $\mathrm{Y}$ box-binding protein 1 in melanoma stimulates proliferation and tumor invasion, antagonizes apoptosis and enhances chemoresistance. Int J Cancer 120: 2110-2118, 2007.

13. Durr UH, Sudheendra US and Ramamoorthy A: LL-37, the only human member of the cathelicidin family of antimicrobial peptides. Biochim Biophys Acta 1758: 1408-1425, 2006.

14. Bucki R, Leszczyńska K, Namiot A and Sokołowski W: Cathelicidin LL-37: A multitask antimicrobial peptide. Arch Immunol Ther Exp (Warsz) 58: 15-25, 2010.

15. Wu WK, Wang G, Coffelt SB, Betancourt AM, Lee CW, Fan D, $\mathrm{Wu} \mathrm{K}$, Yu J, Sung JJ and Cho CH: Emerging roles of the host defense peptide LL-37 in human cancer and its potential therapeutic applications. Int J Cancer 127: 1741-1747, 2010.

16. Coffelt SB and Scandurro AB: Tumors sound the alarmin(s). Cancer Res 68: 6482-6485, 2008.

17. Hensel JA, Chanda D, Kumar S, Sawant A, Grizzle WE, Siegal GP and Ponnazhagan S: LL-37 as a therapeutic target for late stage prostate cancer. Prostate 71: 659-670, 2011.

18. Gill K, Mohanti BK, Singh AK, Mishra B and Dey S: The over expression of cathelicidin peptide LL37 in head and neck squamous cell carcinoma: The peptide marker for the prognosis of cancer. Cancer Biomark 10: 125-134, 2011.
19. Kim JE, Kim HJ, Choi JM, Lee KH, Kim TY, Cho BK, Jung JY, Chung KY, Cho D and Park HJ: The antimicrobial peptide human cationic antimicrobial protein-18/cathelicidin LL-37 as a putative growth factor for malignant melanoma. Br J Dermatol 163: 959-967, 2010.

20. Heilborn JD, Nilsson MF, Jimenez CI, Sandstedt B, Borregaard N, Tham E, Sørensen OE, Weber G and Ståhle M: Antimicrobial protein hCAP18/LL-37 is highly expressed in breast cancer and is a putative growth factor for epithelial cells. Int J Cancer 114: 713-719, 2005.

21. Coffelt SB, Waterman RS, Florez L, Höner zu Bentrup K, Zwezdaryk KJ, Tomchuck SL, LaMarca HL, Danka ES, Morris CA and Scandurro AB: Ovarian cancers overexpress the antimicrobial protein hCAP-18 and its derivative LL-37 increases ovarian cancer cell proliferation and invasion. Int $\mathrm{J}$ Cancer 122: 1030-1039, 2008.

22. von Haussen J, Koczulla R, Shaykhiev R, Herr C, Pinkenburg O, Reimer D, Wiewrodt R, Biesterfeld S, Aigner A, Czubayko F and Bals R: The host defence peptide LL-37/hCAP-18 is a growth factor for lung cancer cells. Lung Cancer 59: 12-23, 2008.

23. Coffelt SB, Tomchuck SL, Zwezdaryk KJ, Danka ES and Scandurro AB: Leucine leucine-37 uses formyl peptide receptor-like 1 to activate signal transduction pathways, stimulate oncogenic gene expression, and enhance the invasiveness of ovarian cancer cells. Mol Cancer Res 7: 907-915, 2009.

24. Coffelt SB, Marini FC, Watson K, Zwezdaryk KJ, Dembinski JL, LaMarca HL, Tomchuck SL, Honer zu Bentrup K, Danka ES, Henkle SL, et al: The pro-inflammatory peptide LL-37 promotes ovarian tumor progression through recruitment of multipotent mesenchymal stromal cells. Proc Natl Acad Sci USA 106: 3806-3811, 2009.

25. Girnita A, Zheng H, Grönberg A, Girnita L and Ståhle M: Identification of the cathelicidin peptide LL-37 as agonist for the type I insulin-like growth factor receptor. Oncogene 31: 352-365, 2012

26. Livak KJ and Schmittgen TD: Analysis of relative gene expression data using real-time quantitative PCR and the 2(-Delta Delta C(T)) Method. Methods 25: 402-408, 2001.

27. Zhao BX, Sun YB, Wang SQ, Duan L, Huo QL, Ren F and Li GF: Grape seed procyanidin reversal of p-glycoprotein associated multi-drug resistance via down-regulation of NF- $\kappa$ B and MAPK/ERK mediated YB-1 activity in A2780/T cells. PLoS One 8: e71071, 2013.

28. Weber G, Chamorro CI, Granath F, Liljegren A, Zreika S, Saidak Z, Sandstedt B, Rotstein S, Mentaverri R, Sánchez F, et al: Human antimicrobial protein hCAP18/LL-37 promotes a metastatic phenotype in breast cancer. Breast Cancer Res 11: R6, 2009.

29. Tjabringa GS, Aarbiou J, Ninaber DK, Drijfhout W, Sørensen OE, Borregaard N, Rabe KF and Hiemstra PS: The antimicrobial peptide LL-37 activates innate immunity at the airway epithelial surface by transactivation of the epidermal growth factor receptor. J Immunol 171: 6690-6696, 2003.

30. Chuang CM, Monie A, Wu A, Mao CP and Hung CF: Treatment with LL-37 peptide enhances antitumor effects induced by $\mathrm{CpG}$ oligodeoxynucleotides against ovarian cancer. Hum Gene Ther 20: 303-313, 2009.

31. Li D, Wang X, Wu JL, Quan WQ, Ma L, Yang F, Wu KY and Wan HY: Tumor-produced versican V1 enhances hCAP18/LL-37 expression in macrophages through activation of TLR2 and vitamin D3 signaling to promote ovarian cancer progression in vitro. PLoS One 8: e56616, 2013.

32. Kittaka M, Shiba H, Kajiya M, Ouhara K, Takeda K, Kanbara K, Fujita T, Kawaguchi H, Komatsuzawa H and Kurihara H: Antimicrobial peptide LL37 promotes vascular endothelial growth factor-A expression in human periodontal ligament cells. J Periodontal Res 48: 228-234, 2013.

33. Yasen $\mathbf{M}$, Kajino $\mathrm{K}$, Kano $\mathrm{S}$, Tobita $\mathrm{H}$, Yamamoto $\mathrm{J}$, Uchiumi T, Kon S, Maeda M, Obulhasim G, Arii S and Hino O: The up-regulation of Y-box binding proteins (DNA binding protein A and Y-box binding protein-1) as prognostic markers of hepatocellular carcinoma. Clin Cancer Res 11: 7354-7361, 2005.

34. Zhang LL, He DL, Li X, Li L, Zhu GD, Zhang D and Wang XY: Overexpression of coxsackie and adenovirus receptor inhibit growth of human bladder cancer cell in vitro and in vivo. Acta Pharmacol Sin 28: 895-900, 2007. 
35. Guay D, Garand C, Reddy S, Schmutte C and Lebel M: The human endonuclease III enzyme is a relevant target to potentiate cisplatin cytotoxicity in Y-box-binding protein-1 overexpressing tumor cells. Cancer Sci 99: 762-769, 2008

36. Shiota M, Yokomizo A, Tada Y,Uchiumi T, Inokuchi J, Tatsugami K, Kuroiwa K, Yamamoto K, Seki N and Naito S: P300/CBP-associated factor regulates Y-box binding protein-1 expression and promotes cancer cell growth, cancer invasion and drug resistance. Cancer Sci 101: 1797-1806, 2010

37. Koike K, Uchiumi T, Ohga T, Toh S, Wada M, Kohno K and Kuwano M: Nuclear translocation of the Y-box binding protein by ultraviolet irradiation. FEBS Lett 417: 390-394, 1997.

38. Oda Y, Ohishi Y, Basaki Y, Kobayashi H, Hirakawa T, Wake N, Ono M, Nishio K, Kuwano M and Tsuneyoshi M: Prognostic implications of the nuclear localization of Y-box-binding protein-1 and CXCR4 expression in ovarian cancer: Their correlation with activated Akt, LRP/MVP and P-glycoprotein expression. Cancer Sci 98: 1020-1026, 2007 .
39. Yang Y, Choi H, Seon M, Cho D and Bang SI: LL-37 stimulates the functions of adipose-derived stromal/stem cells via early growth response 1 and the MAPK pathway. Stem Cell Res Ther 7: 58, 2016.

40. Pistolic J, Cosseau C, Li Y, Yu JJ, Filewod NC, Gellatly S, Rehaume LM, Bowdish DM and Hancock RE: Host defence peptide LL-37 induces IL-6 expression in human bronchial epithelial cells by activation of the NF-kappaB signaling pathway. J Innate Immun 1: 254-267, 2009.

41. Ji BC, Hsiao YP, Tsai CH, Chang SJ, Hsu SC, Liu HC, Huang YP, Lien JC and Chung JG: Cantharidin impairs cell migration and invasion of A375.S2 human melanoma cells by suppressing MMP-2 and -9 through $\mathrm{PI} 3 \mathrm{~K} / \mathrm{NF}-\kappa \mathrm{B}$ signaling pathways. Anticancer Res 35: 729-738, 2015.

42. Xia Y, Shen S and Verma IM: NF- $\kappa B$, an active player in human cancers. Cancer Immunol Res 2: 823-830, 2014. 